\title{
Effect of calcitonin and calcitonin gene-related peptide on pancreatic functions in man
}

\author{
C BEGLinger, E KOEHLER, W BORN, J A FisCHER, U KELlER, \\ L E HANSSEN, AND K GYR
}

From the Division of Gastroenterology and Department of Research, University Hospital, Basel, Switzerland; Research Laboratory for Calcium Metabolism, Departments of Orthopedic Surgery and Medicine, University of Zurich, Zurich, Switzerland and Medical Department A, Rikshospitalet, Oslo, Norway

SUMmaRY Calcitonin gene-related peptide (CGRP) has recently been identified in central and peripheral nerve fibres, including those of blood vessels supplying the exocrine pancreas, and in pancreatic islet cells. Moreover, receptors have been characterised in the same tissue. The present study examined the effects of human CGRP and of calcitonin on exocrine pancreatic secretion and on islet cell function in nine healthy volunteers. CGRP $(300 \mathrm{ng} / \mathrm{kg} / \mathrm{h})$ caused, respectively, a $25 \%$ and $31 \%$ inhibition of caerulein stimulated trypsin and amylase output which was similar to that seen with calcitonin $(300 \mathrm{ng} / \mathrm{kg} / \mathrm{h})$. Arginine stimulated insulin and glucagon release was unaffected by either CGRP, or calcitonin. Calcitonin gene-related peptide caused cutaneous flushing, but did not affect the pulse rate or arterial blood pressure in the doses tested. Calcitonin gene-related peptide inhibits exocrine pancreatic secretion in vivo in man, but does not affect islet cell hormone release.

Calcitonin gene-related peptide (CGRP) is a unique 37 amino acid peptide, which is encoded by the calcitonin gene. 'The peptide has been identified in the central and peripheral nervous system such as in the heart and blood vessels and in the gastrointestinal tract, and in the pituitary and thyroid glands. ${ }^{1-1}$ Little is known so far about the physiological roles of CGRP in man. Recently, CGRP receptors linked to activation of adenylate cyclase have been recognised in the cardiovascular system, and the peptide was shown to exert potent effects in man and rat which include positive chronotropic and inotropic effects on the heart and vasodilation. ${ }^{-x}$ Other effects involve the gastrointestinal tract which include inhibition of gastric acid secretion in rats, dogs, and man, ${ }^{2,12}$ and dose dependent contraction of guinea pig ileal and colonic smooth muscles. ${ }^{13}$

The recent discovery of a specific CGRP receptor on dispersed acini from the guinea pig pancreas and the stimulation of amylase release are consistent with a regulatory role of the peptide on exocrine panAddress for correspondence: Dr Christoph Beglinger. Division of Gastro-
enterology, University Hospital, CH-4031 Basel. Switzerland.

Received for publication 14 August 1987. creatic function. ${ }^{14}$ To this end, CGRP has been localised immunohistochemically in nerve terminals of the islets of Langerhans and in islet cells. ${ }^{+15}$ An action of CGRP on the human pancreas remains to be elucidated. Thus, effects of CGRP have been studied in normal human subjects in vivo on exocrine pancreatic secretion and on the release of islet cell hormones, and compared with those of calcitonin.

\section{Methods}

SUBJECTS

Nine healthy fasting male volunteers (mean age 26 , range 23-34 years; average weight 78 , range 62-91 $\mathrm{kg}$ ) without history of gastrointestinal and endocrine disorders and not receiving any medication have been studied. All subjects gave written and informed consent to the studies undertaken. They were approved by the local Ethical Human Research Committee.

PEPTIDES

Synthetic human CGRP-I (alpha) was purchased from Peninsula Laboratories (Belmont, CA). The 
peptide was dissolved in $0 \cdot 9 \%$ saline containing $0 \cdot 1 \%$ human serum albumin and prepared under aseptic conditions by the University of Basel Hospital Pharmacy. Vials were stored in ampoules of $25 \mu \mathrm{g}$ CGRP at $-20^{\circ} \mathrm{C}$. Synthetic human calcitonin $\left(\right.$ Cibacalcin $\left.^{\mathrm{R}}\right)$ was donated by the Ciba-Geigy Co, Basel, Switzerland, synthetic secretin (Sekretolin ${ }^{\mathrm{R}}$ ) by Hoechst-Pharma, Zurich, Switzerland, and caerulein $\left(\right.$ Takus $^{\mathrm{R}}$ ) by Farmitalia Carlo Erba, Berne, Switzerland.

\section{EXPERIMENTAL. PROCEDURE}

Each subject was studied on different days and in random order.

\section{EXOCRINE PANCREATIC SECRETION STUDIES}

After an overnight fast, gastric and duodenal secretions were collected as described previously. ${ }^{16}$ Briefly, a multilumen tube was positioned under fluoroscopic guidance with the tip lying at the ligamentum of Treitz. Gastric and duodenal secretions were collected separately and continuously on ice in 15 minute aliquots. Polyethylene glycol (PEG) 4000 was perfused into the duodenum as a nonabsorbable marker to correct for intestinal volume losses. After an equilibration period of 30 minutes, exocrine pancreatic secretion was stimulated with iv secretin $(50 \mathrm{ng} / \mathrm{kg} / \mathrm{h}=16.4 \mathrm{pmol} / \mathrm{kg} / \mathrm{h})$ for 150 minutes. After 60 minutes, $10 \mathrm{ng} / \mathrm{kg} / \mathrm{h}$ caerulein $(7 \cdot 4$ $\mathrm{pmol} / \mathrm{kg} / \mathrm{h}$ ) were added to the infusion for the remaining 90 minutes of the experiments. The peptides were dissolved in $0.9 \% \mathrm{NaCl}$ containing $0.1 \%$ human serum albumin ( $\mathrm{wt} / \mathrm{vol})$. The doses used have previously been shown to submaximally stimulate pancreatic secretion ${ }^{16}{ }^{17}$. Seventy five and $300 \mathrm{ng} / \mathrm{kg} / \mathrm{h}$ (20) and $79 \mathrm{pmol} / \mathrm{kg} / \mathrm{h}$ ) CGRP, $300 \mathrm{ng} / \mathrm{kg} / \mathrm{h}(88$ $\mathrm{pmol} / \mathrm{kg} / \mathrm{h})$ calcitonin, and control solutions $(0 \cdot 9 \%$ $\mathrm{NaCl})$ were infused through indwelling catheters positioned in a forearm for the duration of the experiments (150 minutes). Blood samples were obtained in regular intervals at baseline and at 15 minute intervals during the experiments. Blood was collected in ice chilled lithium heparinised tubes containing $5000 \mathrm{KIU}$ aprotinin $/ 5 \mathrm{ml}$ blood. Samples were immediately centrifuged at $4^{\circ} \mathrm{C}$ and the plasma stored at $-20^{\circ} \mathrm{C}$ until assayed for pancreatic polypeptide (PP) and somatostatin by specific radioimmunoassays (RIAs). ${ }^{18} 19$

Secretory volumes were measured to the next millilitre; bicarbonate concentration of the duodenal juice was determined by the back titration method, ${ }^{20}$ trypsin by the method of Wiggins, ${ }^{21}$ amylase according to Rick and Stegbauer,,$^{22}$ and PEG turbidimetrically. ${ }^{23}$ Polyethylene glycol served as a non-absorbable marker to calculate the duodenal volume for a given period by the following equation: $V=(F \times(P E G)$ perf $\times 15) /(\mathrm{PEG}$ meas $)$, where $\mathrm{V}$ is the calculated duodenal volume $(\mathrm{ml} / 15 \mathrm{~min}) ; \mathrm{F}$ is the flow rate of the PEG solution perfused $(2 \mathrm{ml} / \mathrm{min})$; (PEG) perf is the concentration of the perfusate $(2 \mathrm{~g} / \mathrm{l})$; and PEG meas corresponds to the concentration of PEG in the duodenal juice collected during 15 minutes. The recovery of the duodenal marker averaged $77(3 \%)$ (mean [SE]) whereas the average percentage of PEG recovered from the stomach was below $4 \%$. The last three 15 minute aliquots during secretin alone and the six periods under combined stimulation with secretin and caerulein were added in each volunteer to calculate summated outputs per minute. All results are expressed as mean (SEM), if not indicated otherwise. Logarithmic transformation of data was applied when indicated.
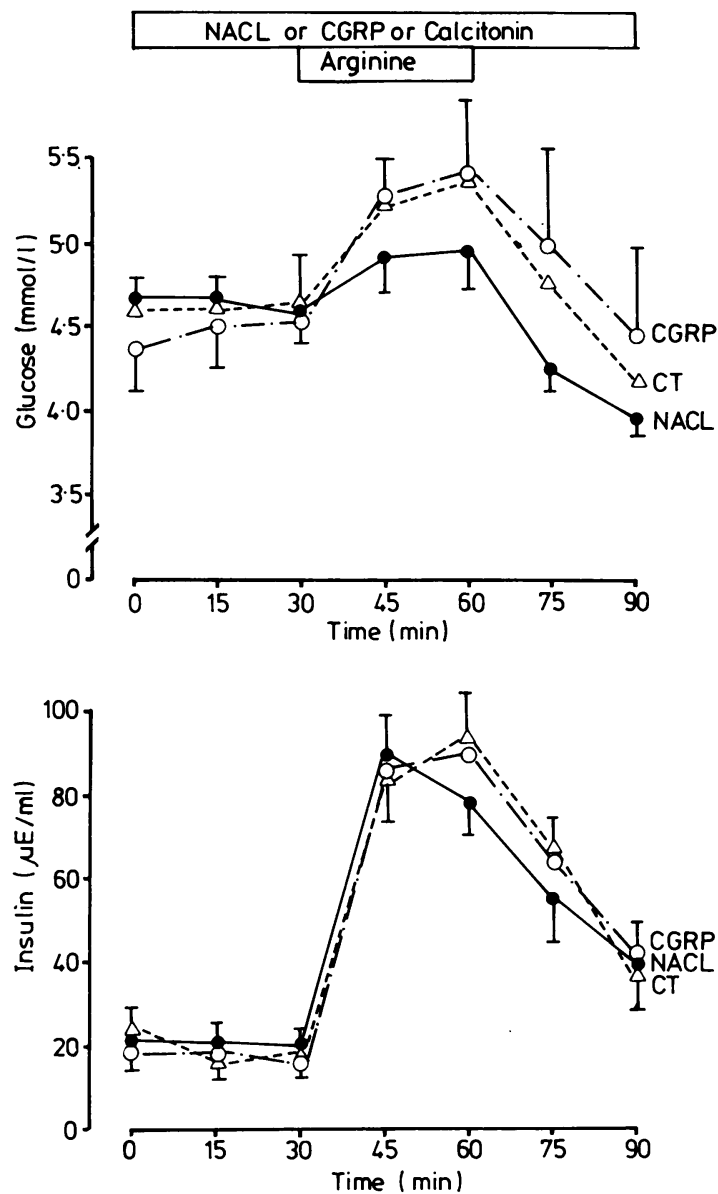

Fig. 1 Effects of intravenous human CGRP and calcitonin on arginine stimulated plasma glucose and insulin release. $n=6$, data are mean (SE). Glucagon results are not shown as they do not add any pertinent information. 

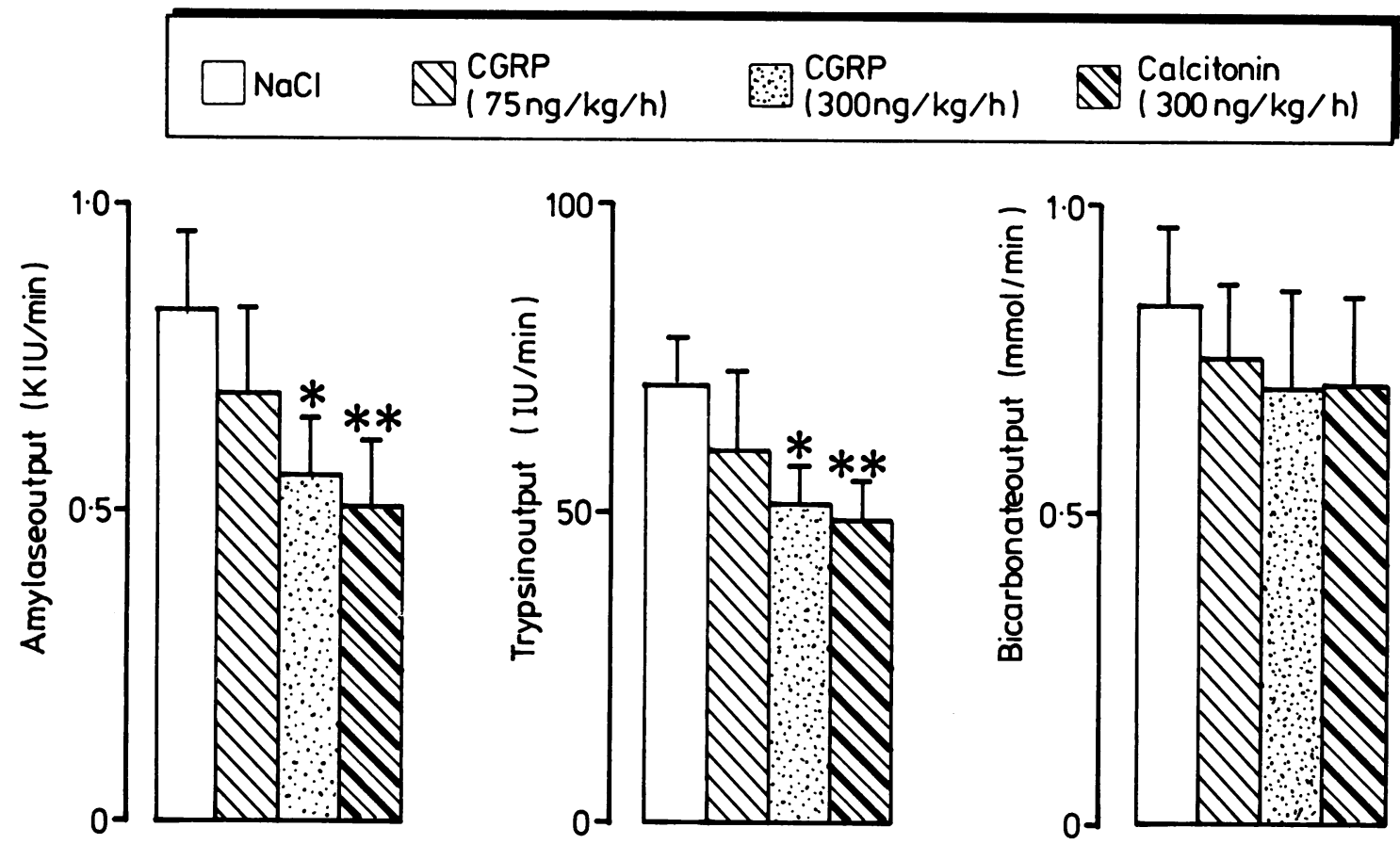

Fig. 2 Summated exocrine pancreatic secretion in response to combined stimulation with secretin and caerulein in the absence or presence of human CGRP and calcitonin. Data are mean $(S E)$ in nine healthy volunteers with the exception of the lower dose of CGRP $(75 \mathrm{ng} / \mathrm{kg} / \mathrm{h})$ where $n=6 .{ }^{*} p<0 \cdot 05,{ }^{* *} p<0 \cdot 01$.

ISLET CELL FUNCTION TESTS

Pancreatic islet cell secretion was stimulated with iv arginine. ${ }^{24}$ After an overnight fast, indwelling catheters were inserted into both cubital veins for blood sampling and for infusions, respectively. Thirty minutes later, blood samples were drawn at 15 minute intervals before, during, and after the administration of arginine- $\mathrm{HCl}(2.8 \mathrm{mmol} / \mathrm{kg})$ diluted in $400 \mathrm{ml} 0.9 \% \mathrm{NaCl}$ as indicated in Figure 1 . On four different days, the subjects received either $0.9 \% \mathrm{NaCl}$ (control), 75 or $300 \mathrm{ng} / \mathrm{kg} / \mathrm{h} \mathrm{CGRP}$ or 300 $\mathrm{ng} / \mathrm{kg} / \mathrm{h}$ calcitonin. Blood was collected as described above and assayed for insulin and glucagon by specific RIAs. ${ }^{24}$ During both, the exocrine pancreatic secretion studies and the islet cell function tests, heart rate and arterial blood pressure were monitored continuously. ${ }^{*}$

STATISTICAL ANALYSIS

Treatment effects in exocrine pancreatic secretory studies were analysed by paired $t$ test. The significance level was set at $p$ less than 0-05. Plasma concentrations of insulin, glucagon, and glucose concentrations were compared in a multi-variate analysis of variance using a commercial SAS program.

\section{Results}

EFFECTS OF CGRP AND CALCITONIN ON EXOCRINE PANCREATIC SECRETION

Combined administration of secretin and caerulein significantly stimulated exocrine pancreatic secretion in all nine subjects and the secretion was maintained with the exception of trypsin output, which tended to decline towards the end of the experiments (not shown). The lower dose of CGRP (75 ng/kg/h)

Table 1 Effects of CGRP and calcitonin on caeruleinstimulated pancreatic polypeptide $(P P)$ release and on somatostatin concentrations (SLI)

\begin{tabular}{|c|c|c|c|c|}
\hline \multirow[t]{2}{*}{ Peptides } & \multicolumn{2}{|c|}{$P P(p M)$} & \multicolumn{2}{|c|}{$S L I(p M)$} \\
\hline & Fasting & $\begin{array}{l}\text { Caerulein } \\
\text { stimulation } \\
\text { (increment } \\
\text { over fasting) }\end{array}$ & Fasting & $\begin{array}{l}\text { Caerulein } \\
\text { stimulation } \\
\text { (increment) }\end{array}$ \\
\hline $\mathrm{NaCl}$ (control) & $4 \cdot 8(0 \cdot 7)$ & $19 \cdot 2(5 \cdot 0)$ & \multicolumn{2}{|c|}{$6.7(2 \cdot 0) 1 \cdot 1(0 \cdot 8)$} \\
\hline CGRP (300 ng/kg/h) & $5 \cdot 3(0 \cdot 8)$ & $15 \cdot 5(5 \cdot 6)$ & \multirow{2}{*}{\multicolumn{2}{|c|}{$\begin{array}{l}4.9(1.0) 0.8(0.6) \\
6.3(2.0) 1.5(0.9)\end{array}$}} \\
\hline Calcitonin $(300 \mathrm{ng} / \mathrm{kg} / \mathrm{h})$ & $5.7(0.7)$ & $4.0(2.0)^{*}$ & & \\
\hline
\end{tabular}

Data are mean (SE) in six healthy volunteers; ${ }^{*}$ indicates $\mathrm{p}<0.01 v$ control. 
slightly decreased pancreatic bicarbonate, trypsin and amylase output, but the difference did not reach statistical significance $(p<0 \cdot 1$, Figure 2$)$. The upper dose of CGRP $(300 / \mathrm{ng} / \mathrm{h})$ and calcitonin, however, significantly reduced pancreatic trypsin and amylase secretion in response to the combined stimulation with secretin and caerulein $(\mathrm{p}<0.05$ and $\mathrm{p}<0.01$ respectively, Fig. 2). The decrease of pancreatic enzyme output brought about with $300 \mathrm{ng} / \mathrm{kg} / \mathrm{h}$ calcitonin was of the same order than with 300 $\mathrm{ng} / \mathrm{kg} / \mathrm{h}$ CGRP.

\section{EFFECTS OF CGRP AND CALCITONIN ON ISLET}

CELL FUNCTION

Basal PP concentrations were comparable and ranged from 4.8 to $7 \cdot 2 \mathrm{pmol} / \mathrm{l}$ (Table 1 ). Caerulein alone stimulated the release of PP $(p<0 \cdot 05)$. Calcitonin gene-related peptide and calcitonin did not affect basal PP concentrations. Stimulation of PP by caerulein was suppressed with calcitonin $(\mathrm{p}<0 \cdot 01)$, whereas CGRP produced a minimal inhibition of PP concentrations which did not reach statistical significance $(\mathrm{p}<0 \cdot 1)$.

Basal somatostatin concentrations were comparable in the different experiments (Table 1). Neither CGRP nor calcitonin affected plasma somatostatin concentrations.

In the arginine infusion tests, basal insulin concentrations tended to decrease during the administration of calcitonin $(p<0 \cdot 1)$ and remained unchanged during CGRP infusions. Arginine-stimulated insulin and glucagon release was unaffected by the administration of CGRP and calcitonin (Fig. 1).

Fasting plasma glucose concentrations ranged from $3 \cdot 8-4.8 \mathrm{mmol} / \mathrm{l}$. In response to arginine infusions, plasma glucose increased significantly with the higher dose of CGRP and with calcitonin $(p<0.05$, Fig. 1), but the area under the curve of glucose concentrations did not show any significant difference from control experiments.

\section{CARDIOVASCULAR EFFECTS OF CGRP AND}

\section{CALCITONIN}

Intravenous administration of CGRP did not change the pulse rate and the arterial blood pressure in the dose range tested in any of the nine subjects (Table 2). Cutaneous flushing of the face, the proximal thorax and occasionally of the palmar side of the hands was observed in all subjects with the higher dose of CGRP $(300 \mathrm{ng} / \mathrm{kg} / \mathrm{h})$. Flushing disappeared within 30 minutes after termination of the CGRP infusions. Flushing was not recognised with 75 $\mathrm{ng} / \mathrm{kg} / \mathrm{h}$ of CGRP and no other side effects were noticed. Calcitonin did not produce changes in the pulse rate, arterial blood pressure, and no flushing was noticed.
Table 2 Comparison of heart rate and arterial blood pressure responses to CGRP, calcitonin or saline (control) in nine healthy volunteers

\begin{tabular}{llllll}
\hline Peptide & \multicolumn{7}{l}{ Time (min) } \\
\cline { 2 - 6 } & -15 & 0 & 30 & 60 & 90 \\
\hline Heart rate & & & & & \\
CGRP(300 ng/kg/h) & $69(3)$ & $68(2)$ & $68(2)$ & $69(2)$ & $69(2)$ \\
Calcitonin & $68(4)$ & $68(1)$ & $69(2)$ & $69(1)$ & $66(3)$ \\
NaCl(control) & $67(2)$ & $67(4)$ & $67(3)$ & $68(2)$ & $66(2)$ \\
Arterial pressure, systolic (mmHg) & & & \\
CGRP(300 ng/kg/h) & $117(3)$ & $116(4)$ & $116(3)$ & $115(3)$ & $118(4)$ \\
Calcitonin & $114(5)$ & $117(3)$ & $117(3)$ & $116(2)$ & $116(3)$ \\
NaCl(control) & $113(3)$ & $115(2)$ & $116(3)$ & $117(2)$ & $117(2)$ \\
Arterial pressure, diastolic(mmHg) & & & \\
CGRP(300 ng/kg/h) & $73(4)$ & $73(3)$ & $72(3)$ & $72(2)$ & $73(3)$ \\
Calcitonin & $75(3)$ & $72(2)$ & $71(2)$ & $72(3)$ & $72(2)$ \\
NaCl(control) & $72(2)$ & $71(3)$ & $72(3)$ & $73(4)$ & $73(2)$ \\
\hline
\end{tabular}

Data are mean (SE).

\section{Discussion}

The wide spread presence of CGRP in peripheral nerves - for example, around the blood vessels of the gastrointestinal tract and the pancreatic islets of Langerhans suggests physiological roles of the peptide. . $^{-121415}$ The exocrine pancreas has only few CGRP fibres stained by immunohistochemistry, but the peptide may reach the acinar cells through the insuloacinar portal system and act as a paracrine agent. ${ }^{25}$ Moreover, stimulation of amylase secretion in guinea pig acinar cells by CGRP is presumably linked to a CGRP receptor and stimulation of cyclic AMP production. ${ }^{14}$ Furthermore, in this in vitro system CGRP enhanced amylase release stimulated by agents which act through mobilisation of intracellular calcium such as cholecystokinin or acetylcholine.$^{14}$ Calcitonin gene-related peptide, however, did not influence the pancreatic secretory response to an intragastric meal of liver extracts in conscious dogs."

Here we describe for the first time effects of human CGRP on pancreatic function in normal human subjects. Infusion of $300 \mu \mathrm{g} / \mathrm{kg} / \mathrm{h}$ CGRP resulted in a small significant decrease of caerulein stimulated pancreatic enzyme secretion and was of the same magnitude as the calcitonin induced inhibition of pancreatic enzyme release. Previous studies have shown inhibition of exocrine pancreatic function with human calcitonin in man, but have been obtained with far higher amounts of the peptide. ${ }^{2027}$ At the doses of CGRP used in the present study, marked facial flushing occurred giving further evidence for the cardiovascular properties and presumably pharmacological potency of the peptide used. The 
CGRP and calcitonin induced inhibition of the exocrine secretory response was not caused by somatostatin release, as neither calcitonin nor CGRP affected circulating plasma somatostatin concentrations.

Calcitonin has been shown to inhibit glucose and arginine stimulated islet cell functions in man..$^{28}{ }^{29}$ The doses used, however, were at least 15 times higher than in the present study. Here neither human CGRP nor calcitonin affected plasma insulin and glucagon concentrations, but calcitonin suppressed caerulein stimulated PP release. It remains to be established, if this finding has physiological relevance. Several gastrotintestinal hormones stimulate calcitonin secretion such as gastrin and the cholecystokinin peptides. ${ }^{3131}$ Here again, the effects were obtained with pharmacological rather than physiological amounts. Thus, physiological effects of calcitonin on islet cell function are unlikely to be important in man.

In view of the cutaneous flushing seen here and earlier, ${ }^{8}$ transcutaneous Doppler ultrasound measurements of the blood flow in the superior mesenteric artery and for comparison in the common carotid artery were obtained in healthy volunteers. While the blood flow of the superior mesenteric artery was slightly reduced by the same doses of CGRP, a marked increase in carotid blood flow was observed especially with the higher dose of CGRP (manuscript submitted).

In conclusion, the present study has revealed that iv human CGRP, unlike in vitro, induces a small inhibition of exocrine pancreatic enzyme secretion in healthy volunteers, whereas the endocrine pancreas does not appear to be an important target for the peptide. Cutaneous flushing observed here and in previous studies ${ }^{58}$ suggests important cardiovascular properties. We conclude that CGRP might be a regulatory peptide in the human gastrointestinal tract, but more studies are required to define its action and establish a physiological role.

We thank Mrs Carita Frei for editorial assistance and for typing the manuscript. We further thank Miss Sylvia Ketterer for expert technical assistance and $\mathrm{Mr}$ L Varga for measuring plasma PP concentrations. This study was supported by grants no 3.866.0.85 and no 3.957.0.84 of the Swiss National Science Foundation and the Kanton of Zurich. Part of this study has been presented at the American Gastroenterological Association Meeting held in San Francisco (May 17-23, 1986) and was published in abstract form (Gastroenterology 1986; 90: 1342).

\section{References}

1 Rosenfeld MG, Mermod JJ, Amara SG, et al. Production of novel neuropeptide encoded by the calcitonin gene via tissue specific RNA processing. Nature 1983; 304: 129-35.

2 Tschopp FA, Tobler PH, Fischer JA. Calcitonin generelated peptide in the human thyroid, pituitary and brain. Mol Cell Endocrinol 1984; 36: 53-7.

3 Mulderry PK, Ghatei MA, Rodrigo J, et al. Calcitonin gene-related peptide in cardiovascular tissues of the rat. Neuroscience 1985; 14: 947-54.

4 Mulderry PK, Ghatei MA, Bishop AE, Allen YS, Polak JM, Bloom SR. Distribution and chromatographic characterisation of CGRP-like immunoreactivity in the brain and gut of the rat. Reg Peptides 1985; 12: 133-43.

5 Sigrist S, Franco-Cereceda A, Muff R, Henke H, Lundberg JM, Fischer JA. Specific receptor and cardiovascular effects of calcitonin gene-related peptide. Endocrinology 1986; 119: 381-9.

6 Fischer LA, Kikkawa DO, Rivier JE, et al. Stimulation of noradrenergic sympathetic outflow by calcitonin gene-related peptide. Nature 1983; 305: 534-6.

7 Brain SD, Williams TJ, Tippins JR, Morris HR, MacIntyre I. Calcitonin gene-related peptide is a potent vasodilator. Nature $1985 ; 313$ : 54-6.

8 Gennari C, Fischer JA. Cardiovascular action of calcitonin gene-related peptide in humans. Calcif Tissue Int 1985; 37: 581-4.

9 Lenz HJ, Mortrud MT, Rivier JE, Brown MR. Calcitonin gene related peptide inhibits basal, pentagastrin, histamine, and bethanecol stimulated gastric acid secretion. Gut 1985; 26: 550-5.

10 Taché Y, Pappas T, Lauffenburger M, Goto Y, Walsh JH, Debas H. Calcitonin gene-related peptide: Potent peripheral inhibitor of gastric acid secretion in rats and dogs. Gastroenterology 1984; 87: 344-9.

11 Pappas T, Debas HT, Walsh JH, Rivier J, Taché Y. Calcitonin gene-related peptide-induced selective inhibition of gastric acid secretion in dogs. Am J Physiol 1986; 250: G127-33.

12 Kraenzlin ME, Ch'ng JLC, Mulderry PK, Ghatei MA, Bloom SR. Infusion of a novel peptide, calcitonin generelated peptide (CGRP) in man. Pharmacokinetics and effects on gastric acid secretion and on gastrointestinal hormones. Reg Peptides 1985; 10: 189-97.

13 Ghatei MA, Christofides ND, Bishop AE, et al. Distribution and effect of calcitonin gene-related peptide in the gastrointestinal tract of the guinea pig. Reg Peptides 1984; 9: 330.

14 Seifert H, Sawchenko P, Chesnut J, Rivier J, Vale W, Pandol SJ. Receptor for calcitonin gene-related peptide: binding to exocrine pancreas mediates biological actions. Am J Physiol 1985; 249: G147-51.

15 Sternini C, Brecha N. Immunocytochemical identification of islet cells and nerve fibers containing calcitonin gene-related peptide-like immunoreactivity in the rat pancreas. Gastroenterology 1986; 90: 1155-63.

16 Beglinger C, Fried M, Whitehouse I, Jansen JB, Lamers $\mathrm{CB}, \mathrm{Gyr} \mathrm{K}$. Pancreatic enzyme response to a liquid meal and to hormonal stimulation. Correlation with plasma secretin and cholecystokinin levels. J Clin Invest 1985; 75: $1471-6$.

17 Beglinger C, Köhler E, Stalder GA, Jansen J, Gyr K. What is the maximum effective dose of caerulein in 
stimulating pancreatic secretion in man? Digestion 1986; 35: $57-60$.

18 Meyer FD, Gyr K, Häcki W, et al. The release of pancreatic polypeptide by CCK-octapeptide and some analogues in the dog. Gastroenterology 1981; 80: 742-7.

19 Skare S, Hanssen KF, Kriz V, Torgjesen PA. Arginine infusion increases peripheral plasma somatostatin in man. Clin Endocrinol 1984; 21 : 299-308.

20 Lagerlöf HO. Pancreatic function and pancreatic disease studied by means of secretin. Acta Med Scand 1942; suppl 128: 1-289.

21 Wiggins HS. Simple method for estimating trypsin. Gut 1967; 8: 415-6.

22 Rick W, Stegbauer H. Zur Bestimmung der Amylaseaktivität im Darm. Fresenius $Z$ Anal Chem 1968; 243: 415-6.

23 Hydén S. A turbidimetric method for the determination of higher polyethylene glycols in biological materials. Kungl Lantbrukshögskolans Ann 1955; 22: 139-45.

24 Keller E, Szöllösy E, Varga L, Gyr K. Pancreatic glucagon secretion and exocrine function (BT-PABA test) in chronic pancreatitis. Dig Dis Sci 1984; 29: 853-7.
25 Williams JA, Goldfine ID. The insulin-pancreatic acinar axis. Diabetes 1985; 34: 980-6.

26 Hotz J, Goebell H, Ziegler R. Calcitonin and exocrine pancreatic secretion in man: inhibition of enzymes stimulated by CCK-pancreozymin, caerulein, or calcium - no response to vagal stimulation. Gut 1977; 18: 615-22.

27 Hotz J, Goebell H. Pharmacological actions of calcitonin on the gastrointestinal tract and their therapeutical implications. Z Gastroenterol 1981; 19: 637-45.

28 Giugliano D, Passariello N, Sgambato S, Torella R, D'Onofrio F. Calcitonin modulation of insulin and glucagon secretion in man. Am J Physiol 1982; 242: E206-13.

29 Sgambato S, Passariello N, Giugliano D, D'Onofrio F. Effect of calcitonin on insulin response to arginine in man. Diabete Metab 1979; 5: 213-6.

30 Stevenson JC, Adrian TE, Christofides ND, Bloom SR. Effect of calcitonin on gastrointestinal regulatory peptides in man. Clin Endocrinol 1985; 22: 655-60.

31 Telenius-Berg M. Diagnostic studies in medullary carcinoma of the thyroid. Acta Med Scand 1976; suppl 596: 1-59. 